OPEN ACCESS

Edited by:

Christopher Irwin Smith, Willamette University, United States

Reviewed by:

Carlos A. Machado, University of Maryland, College Park,

United States

David Althoff,

Syracuse University, United States

*Correspondence:

Jared Bernard

bernardj@hawaii.edu

Specialty section:

This article was submitted to

Coevolution,

a section of the journal

Frontiers in Ecology and Evolution

Received: 22 May 2020

Accepted: 29 October 2020

Published: 19 November 2020

Citation:

Bernard J, Brock KC, Tonnell V, Walsh SK, Wenger JP, Wolkis D and

Weiblen GD (2020) New Species

Assemblages Disrupt Obligatory Mutualisms Between Figs and Their

Pollinators.

Front. Ecol. Evol. 8:564653. doi: $10.3389 /$ fevo.2020.564653

\section{New Species Assemblages Disrupt Obligatory Mutualisms Between Figs and Their Pollinators}

\author{
Jared Bernard ${ }^{1 *}$, Kelsey C. Brock ${ }^{2,3,4}$, Veronica Tonnell5, Seana K. Walsh", \\ Jonathan P. Wenger ${ }^{5}$, Dustin Wolkis ${ }^{4}$ and George D. Weiblen ${ }^{5}$
}

\begin{abstract}
${ }^{1}$ Plant and Environmental Protection Sciences, University of Hawaii-Manoa, Honolulu, HI, United States, ${ }^{2}$ School of Life Sciences, University of Hawaii-Manoa, Honolulu, HI, United States, ${ }^{3}$ Kauai Invasive Species Committee, University of Hawaii-Manoa, Kapaa, HI, United States, ${ }^{4}$ Department of Science and Conservation, National Tropical Botanical Garden, Kalaheo, HI, United States, ${ }^{5}$ Plant and Microbial Biology, University of Minnesota-Twin Cities, Saint Paul, MN, United States
\end{abstract}

The reliance of each fig species on its specific pollinator wasp, and vice versa, is the archetype of both obligatory mutualism and coevolution. Pollinator sharing between host fig species is only known to occur among closely related sympatric species. On the Hawaiian island of Kauai, we gathered syconia from 23 non-native fig species, three of which contained the wasp Pleistodontes imperialis. Of the three fig species, one is the wasp's natural host, Ficus rubiginosa, and another is its sister species, Ficus watkinsiana, which overlaps in native ranges, although researchers have not previously documented pollinator sharing. The third fig species, Ficus rubra, is distant to the others both in terms of phylogenetic relationship and native range. We found viable seeds for all three fig species, whereas species without wasps did not produce seeds. To investigate similarity between these pollinator-sharing fig species, we collected morphometric data for syconia of our study fig species. We found that fig species with and without $P$. imperialis significantly differ based on the orientation of their inner ostiolar bracts. These findings suggest that pollinator sharing among these three fig species may normally be impeded by pollinator competition in the case of $F$. watkinsiana, and by geographic distance in the case of F. rubra. This work therefore demonstrates that coevolution depends on interactions within native species assemblages, and that mutualisms can be disrupted in new non-native communities.

Keywords: codiversification, convergent evolution, Ficus, fig wasps, fundamental niche, geographic mosaic theory, host breadth expansion, symbiosis

\section{INTRODUCTION}

Coevolution is the reciprocal evolution of traits between interacting species (Thompson, 2005) and is thus a major driver of biodiversity, as seen in the vast diversity of insects and flowering plants (Ehrlich and Raven, 1964; Lunau, 2004; Wiens et al., 2015). Certain insect groups that are closely associated with plants have diversification rates that reflect those of their host plants (Danforth and Ascher, 1999; Janz et al., 2006; Kawakita and Kato, 2009; Shimizu et al., 2015; Winter et al., 2017; McKenna et al., 2019). Coevolution can result in strictly obligatory symbiotic relationships, including obligatory mutualisms, which involve cospeciation demonstrated by 
mirrored phylogenies (Hafner and Page, 1995; Pellmyr and Leebens-Mack, 1999; Jousselin et al., 2009; Percy, 2010).

One of the strongest cases of coevolution is between figs (Moraceae: Ficus) and their pollinator wasps (Chalcidoidea: Agaonidae), in which each depends upon the other to complete its life cycle (Ramírez-Benavides, 1970; Weiblen, 2002; Cruaud et al., 2012b). In particular, a specialized wasp must go through a minute labyrinthine portal known as an ostiole on a fig's closed involuted inflorescence (i.e., syconium or "fig") to deposit eggs into the ovules it can reach and pollinate those it cannot (Weiblen, 2002; Cook and Rasplus, 2003). To maintain the mutualism, the fig emits volatile organic compounds (GrisonPigé et al., 2002; Hossaert-McKey et al., 2010; Souto-Vilarós et al., 2018) that attract a specific pollinator whose ovipositor length complements its flower styles (Herre et al., 2008). Chemical cues on the surface of the syconium (Wang et al., 2013) and the size of the wasp relative to the ostiole (Liu et al., 2013) likely also play important roles. As a result, this strong relationship is formed not by host-switching (Moe and Weiblen, 2010) but by coevolution of figs and fig wasps that largely results in cospeciation, with one obligatory pollinator species for each fig species (Anstett et al., 1997; Lopez-Vaamonde et al., 2001; Cook and Rasplus, 2003; Rønsted et al., 2005; Cruaud et al., 2012b). The interdependency of figs and their specific pollinators reinforces the obligatory mutualisms, and hybridization is hypothetically rare (Moe and Weiblen, 2012; Yang et al., 2012; Souto-Vilarós et al., 2018).

However, other studies have exposed inconsistencies in the cospeciation of figs and their pollinators (Machado et al., 2005; Cruaud et al., 2012a; Yang et al., 2015). Researchers have encountered cases of pollinator sharing, which is the sharing of a single pollinator among multiple figs (Wei et al., 2014; Wang et al., 2016), and co-pollination, whereby a single fig species has multiple pollinators (Compton et al., 2009; Wachi et al., 2016). Nonetheless, such exceptions to cospeciation involve sympatric closely related fig species complexes (e.g., Cornille et al., 2012). For the most part, fig species within these complexes maintain genetic distinction, but there are instances of hybridization (Tsai et al., 2015). No work has so far determined whether pollinator sharing or co-pollination can exist across species that are more distantly related than sympatric complexes.

Importantly, the geographic mosaic theory describes that the mechanisms supporting a mutualism evolve in response to interactions within a given species assemblage (i.e., community), where natural selection favors traits that strengthen the relationship between partners while excluding other species interactions (Thompson, 2005). In other words, coevolution is dependent on the species interactions in a given location that is more conducive to the partnership (Thompson, 2005), yet natural selection for host specificity can obviously only act on sympatric species. But, the human-aided dispersal of nonnative species worldwide creates new communities (van Kleunen et al., 2015) in which obligatory mutualisms are exposed to new species interactions they did not evolve to counter. The new species assemblage could be missing a key interaction that normally encourages niche differentiation or could include new interactions with species that have evolved analogous traits (i.e., convergent evolution). These situations would thus disrupt the obligatory mutualism, because the species would no longer interact solely with its unique partner. Coyne and Orr (2004, p. 189) assert that cospeciation requires one-to-one obligatory partnerships, as opposed to codiversification whereby groups are coevolving but not necessarily by strict relationships (e.g., Winter et al., 2017; McKenna et al., 2019). By this definition, if a fig forms a new facultative pollinator relationship in a new community, the original relationship will no longer be obligatory and there would be less pressure to maintain it.

The Hawaiian island of Kauai has the potential to shed light on whether mutualisms will be compromised in a new community, having no native figs or fig wasps but $\sim 45$ cultivated nonnative fig species. Foresters purposefully introduced three fig species alongside their obligatory pollinators, and only one of these figs, Ficus microcarpa L.f., is documented as naturalized (Timberlake, 1924; Beardsley, 1998). A recent botanical survey found additional non-native fig species that are potentially in the early phases of naturalizing on the island (detailed herein), but without knowledge of the arrival of their natural pollinating wasps. A fig species theoretically requires the arrival of its specific pollinator to naturalize, although the restricted life cycle of fig wasps reduces the odds of accidental introductions. We therefore question whether newly establishing fig species could involve new relationships with pollinators that are already present. Given Kauai's unnatural combination of non-native figs from across the world, we furthermore suspect that new instances of pollinator sharing could manifest between distantly related figs, and thus phylogenetic relationship would be unable to explain them as it could for previously studied examples of pollinatorsharing figs. To explore whether convergent evolution can lead to novel pollinator sharing among co-occurring non-native figs, we collected syconia from nearly two dozen fig species across Kauai, examined any seeds and wasps present, and performed a morphometric analysis.

\section{MATERIALS AND METHODS}

From January-June 2017, we gathered an average of 24 syconia at various stages of development from each of 23 fig species, which included five subgenera, 10 sections, and 12 subsections (three of the sectional lineages in our study do not contain subsections). Most of Kauai's fig species have not escaped cultivation and are therefore sparsely distributed on private land, so our collections were opportunistic and often confined to the National Tropical Botanical Garden in Kalaheo. Although Ficus microcarpa is naturalized, we found it bearing syconia only once. Unfortunately this means the only fig species for which we were able to sample multiple trees were those that appeared to be in the early stages of naturalizing (individual tree locations in Supplementary Table 1). This level of sampling is nevertheless expected considering we were exploring new pollinator interactions among unestablished or newly establishing figs.

Under a stereo microscope, we dissected each syconium and collected any present fig wasps for identification and any present seeds to assess their viability to demonstrate successful pollination. We define a successful interaction as the ability for 
both figs and wasps to reproduce, rather than frequency of the relationship, because the non-native species assemblage of figs on Kauai is less than a century old, hence new interactions may be in the process of emerging and not yet fully stabilized. The formation of new pollinator interactions is particularly important to understand in the context of non-native fig species that may naturalize.

\section{Identifying Figs and Wasps}

For taxonomic identification of pollinator wasps (i.e., Agaonidae) and non-pollinator wasps (e.g., Pteromalidae), we followed Ishii (1934), Wiebes (1964), Berg and Wiebes (1992), Wiebes (1994), van Noort and Rasplus (1997), Beardsley (1998), Beardsley and Rasplus (2001), Lopez-Vaamonde et al. (2002), van Noort and Rasplus (2010), and van Noort et al. (2013). To crosscheck the identity of wasps using new hosts, we sequenced the mitochondrial gene for cytochrome b (cytB) following the protocols described by Lopez-Vaamonde et al. (2001). Dichotomous keys for identifying figs included Corner (1965), Berg and Wiebes (1992), and Dixon (2003). In the case of multiple individuals of the same wild-growing fig species, we corroborated our taxonomic identification by sequencing the nuclear ribosomal internal transcribed spacer region (ITS1, 5.8S, and ITS2) according to methods outlined by Weiblen (2000) and Rønsted et al. (2008). Voucher specimens of both figs and wasps are at the Bernice Pauahi Bishop Museum in Honolulu and the National Tropical Botanical Garden in Kalaheo, Kauai (listed in Supplementary Material). We also deposited wasp vouchers at the University of Hawaii Insect Museum and the Hawaii Department of Agriculture, both in Honolulu. Genetic sequences are on GenBank (accession numbers in Supplementary Table 1).

\section{Germination Assays}

We sowed three to nine replicates of 25-50 seeds on seed germination paper (Anchor Paper, St. Paul, MN, United States) in $60-\mathrm{mm}$ Petri dishes. We moistened the germination paper with a solution of $0.1 \%$ Plant Preservative Mixture ${ }^{\mathrm{TM}}$ (Plant Cell Technology, Washington, DC, United States) in distilled water to inhibit fungal growth without affecting germination (Assaf Guri, personal communication). After sealing dishes with Parafilm ${ }^{\circledR}$ (Bemis, Oshkosh, WI, United States) to increase water retention, we placed them in a GR-36L germination chamber (Percival Scientific, Perry, IA, United States) with a photoperiod of $12 \mathrm{~h}$ light $\left[\sim 41 \mathrm{mmol} / \mathrm{m}^{2} / \mathrm{s} \mathrm{cool}\right.$ white $(4100 \mathrm{~K})$ fluorescent light $]$ and $12 \mathrm{~h}$ dark, and respective temperature regimens of 25 and $15^{\circ} \mathrm{C}$. We monitored seeds until they all germinated or died, or until at least 30 days elapsed since date sown, and defined germination as radicle emergence.

\section{Morphometric Data Collection}

For each of the $23 \mathrm{fig}$ species in our study, we collected morphological data regarding the syconium and the ostiole through which a wasp must navigate to reach the flowers in the interior. In other words, these characters physically restrict which wasp species could enter the syconium (Table 1). We included two continuous variables, mean syconium diameter and mean ostiole diameter, because size limitations could directly impede wasps (Tsai et al., 2015). Raw data for these two variables, as well as pollinators per syconium, are on Figshare (doi: 10.6084/m9.figshare.12927287.v). We also had four categorical variables: (i) mode of reproduction (monoecy versus gynodioecy, in which different mechanisms entail different life cycles for pollinators; Suleman et al., 2015; Yang et al., 2015; Wachi et al., 2016); (ii) presence of lateral bracts on the syconium (which may not directly affect wasps but could indirectly coincide with other traits that do); (iii) external shape of the ostiole (flat, nearly flat, or convex); and (iv) the orientation of the ostiole's internal bracts (interlocking versus linearly descending into the syconium's inner cavity). The latter two traits confront a wasp with obstacles that require different skills, which may be reflected in head morphology (van Noort and Compton, 1996). To aid our characterization of ostiole morphology, we followed Corner (1962), Berg (1989), Verkerke (1989), and Berg and Wiebes (1992). Seed germination and a new generation of wasps emerging from fig ovaries demonstrate a wasp's success in both pollination and oviposition once it reaches the interior of the syconium.

\section{Data Analysis}

To assess the morphological similarity of any species that share pollinators among the 23 study figs, we first assigned numerical character states to categorical data so we could construct ordinations in $\mathrm{R}$ ( $\mathrm{R}$ Core Team, 2019). A principal component analysis (PCA) of fig species allowed us to explore multidimensional trends in variation, visualized with the package rgl (Adler et al., 2018). We then used candisc (Friendly and Fox, 2017) to do a canonical discriminant analysis (CDA) to account for within- and between-group variation. A KolmogorovSmirnov test evaluated the normality of our morphometric data. To test the significance of morphological variables in influencing the presence of any shared pollinators, we first performed a multivariate logistic regression with Monte Carlo resampling at 1000 bootstraps using MVabund (Wang et al., 2012, 2019), which also provided a likelihood ratio test. We then conducted univariate Kruskal-Wallis analyses of variance followed by a post hoc Dunn's multiple comparison test using Bonferroni correction via the package dunn.test (Dinno, 2017).

\section{RESULTS}

Three of the 23 fig species in our study had saplings near mature trees, possibly indicating early stages of naturalization, which were not previously documented on Kauai (Table 1; detailed in Supplementary Material). Aside from detecting three species of pollinating wasps that landscapers intentionally introduced in the early 20th century (Timberlake, 1924; Beardsley, 1998), we also found two pollinating wasp species in the genus Platyscapa that were not recorded for the Hawaiian archipelago, as well as four new records of non-pollinating wasp species (Table 1; detailed in Supplementary Material), extending the known nonnative ranges of these species (Beardsley, 1999; Bain et al., 2015; Wang et al., 2015). Numbers of wasps per fig species are in Table 1 (detailed per tree in Supplementary Table 1). 
TABLE 1 | Morphometric and seed germination data for non-native fig species on Kauai, alongside any wasps present; metrics in mean \pm standard deviation; $N=$ previously known naturalized species; ${ }^{A}=$ new naturalization record for the Hawaiian archipelago; ${ }^{\prime}=$ new naturalization record for Kauai Island but known on other Hawailan islands; ${ }^{P}=$ new potentially naturalizing species on Kauai; ${ }^{S}=$ species outside of cultivation but without self-sustaining wild populations (see details in

Supplementary Material).

\begin{tabular}{|c|c|c|c|c|c|c|c|c|c|c|}
\hline Ficus species & $\begin{array}{l}\text { Mode of } \\
\text { reproduction }\end{array}$ & $\begin{array}{l}\text { Syconia } \\
\text { collected }\end{array}$ & $\begin{array}{c}\text { Syconium } \\
\text { diameter } \\
\text { mean } \pm \\
\text { sd (mm) }\end{array}$ & $\begin{array}{l}\text { Lateral } \\
\text { bracts }\end{array}$ & $\begin{array}{c}\text { Ostiole } \\
\text { diameter } \\
\text { mean } \pm \\
\text { sd }(\mathrm{mm})\end{array}$ & $\begin{array}{l}\text { Inner } \\
\text { ostiolar } \\
\text { bracts }\end{array}$ & $\begin{array}{l}\text { External } \\
\text { ostiole } \\
\text { shape }\end{array}$ & $\begin{array}{l}\text { Pollinator wasp } \\
\text { found (number) }\end{array}$ & $\begin{array}{l}\text { Seeds } \\
\text { germi- } \\
\text { nated }\end{array}$ & $\begin{array}{l}\text { Non-pollinating } \\
\text { wasps found } \\
\text { (number) }\end{array}$ \\
\hline F. altissima Blume & monoecious & 28 & $22.5 \pm 2.8$ & absent & $2.3 \pm 0.2$ & Interlocking & Convex & None & & $\begin{array}{l}\text { Josephiella } \\
\text { microcarpae } \\
\text { Beardsley \& } \\
\text { Rasplus }^{N}(2)\end{array}$ \\
\hline F. benghalensis L. & monoecious & 5 & $17.5 \pm 0.9$ & absent & $1.5 \pm 0.2$ & Interlocking & $\begin{array}{l}\text { Shallowly } \\
\text { convex }\end{array}$ & None & & None \\
\hline F. benjamina L. & monoecious & 31 & $10.0 \pm 1.1$ & absent & $1.1 \pm 0.1$ & Interlocking & $\begin{array}{l}\text { Shallowly } \\
\text { convex }\end{array}$ & None & & None \\
\hline F. boninsimae Koidz. & gynodioecious & 21 & $7.5 \pm 0.7$ & present & $1.1 \pm 0.1$ & Interlocking & Convex & None & & None \\
\hline F. drupacea Thunb. & monoecious & 10 & $20.0 \pm 2.0$ & absent & $2.4 \pm 0.2$ & Interlocking & Convex & None & & None \\
\hline $\begin{array}{l}\text { F. elastica Roxb. ex } \\
\text { Hornem. }\end{array}$ & monoecious & 18 & $11.0 \pm 0.6$ & absent & $1.0 \pm 0.2$ & Interlocking & Convex & None & & None \\
\hline $\begin{array}{l}\text { F. macrophylla } \\
\text { Desf. ex Pers. }\end{array}$ & monoecious & 26 & $21.8 \pm 2.0$ & absent & $2.0 \pm 0.3$ & Linear & $\begin{array}{l}\text { Shallowly } \\
\text { convex }\end{array}$ & $\begin{array}{l}\text { Pleistodontes } \\
\text { froggatti Mayr }^{N} \\
(176)\end{array}$ & Yes & None \\
\hline F. microcarpa L.f. ${ }^{N}$ & monoecious & 40 & $8.0 \pm 1.1$ & absent & $0.5 \pm 0.1$ & Interlocking & Convex & $\begin{array}{l}\text { Eupristina } \\
\text { verticillata Waterston } \\
\text { (1) }\end{array}$ & $N^{\text {Yes }}$ & $\begin{array}{l}\text { Philotrypesis emeryi } \\
\text { Grandi }^{\prime}(11), \\
\text { Sycoscapter cf } \\
\text { gajimaru (Ishii) }{ }^{A}(20) \text {, } \\
\text { Walkerella } \\
\text { microcarpae } \\
\text { Bouèek' (73) }\end{array}$ \\
\hline F. nota (Blanco) Merr. & monoecious & 21 & $27.5 \pm 2.0$ & absent & $7.5 \pm 0.3$ & Interlocking & Convex & None & & None \\
\hline F. prolixa G.Forst. & monoecious & 18 & $7.0 \pm 0.4$ & absent & $1.2 \pm 0.1$ & Interlocking & $\begin{array}{l}\text { Shallowly } \\
\text { convex }\end{array}$ & None & & None \\
\hline F. pumila L. & gynodioecious & 16 & $52.5 \pm 2.5$ & present & $10.9 \pm 0.4$ & Interlocking & Convex & None & & None \\
\hline F. religiosa L.P & monoecious & 33 & $12.5 \pm 0.9$ & absent & $2.5 \pm 0.3$ & Interlocking & Convex & $\begin{array}{l}\text { Platyscapa } \\
\text { quadraticeps (Mayr) } \\
(176)\end{array}$ & Yes & $\begin{array}{l}\text { Otitesella digitata } \\
\text { Westwood }^{A}(10)\end{array}$ \\
\hline $\begin{array}{l}\text { F. rubiginosa Desf. ex } \\
\text { Vent. }\end{array}$ & monoecious & 36 & $14.0 \pm 1.9$ & absent & $1.3 \pm 0.2$ & Linear & Flat & $\begin{array}{l}\text { Pleistodontes } \\
\text { imperialis Saunders }^{N} \\
(183)\end{array}$ & Yes & None \\
\hline F. rubra Vahl & monoecious & 40 & $17.0 \pm 1.7$ & absent & $3.5 \pm 0.2$ & Linear & $\begin{array}{l}\text { Shallowly } \\
\text { convex }\end{array}$ & $\begin{array}{l}\text { Pleistodontes } \\
\text { imperialis Saunders }^{N} \\
\text { (23) }\end{array}$ & Yes & None \\
\hline $\begin{array}{l}\text { F. saussureana De } \\
\text { Candolle }\end{array}$ & monoecious & 30 & $22.5 \pm 4.1$ & absent & $2.4 \pm 0.2$ & Linear & Flat & None & & None \\
\hline F. scabra G.Forst. & gynodioecious & 31 & $17.5 \pm 3.6$ & absent & $4.3 \pm 0.2$ & Interlocking & Convex & None & & None \\
\hline F. superba Miq. & monoecious & 18 & $21.0 \pm 1.6$ & absent & $2.3 \pm 0.3$ & Interlocking & Flat & None & & None \\
\hline F. sycomorus L. & monoecious & 18 & $25.0 \pm 1.5$ & absent & $4.0 \pm 0.2$ & Interlocking & Convex & None & & None \\
\hline F. tinctoria G.Forst. & gynodioecious & 38 & $9.0 \pm 0.4$ & present & $1.5 \pm 0.1$ & Interlocking & Flat & None & & None \\
\hline F. trigonata L. & monoecious & 18 & $22.5 \pm 2.3$ & absent & $5.0 \pm 0.2$ & Interlocking & Convex & None & & None \\
\hline $\begin{array}{l}\text { F. vallis-choudae } \\
\text { Delile }\end{array}$ & monoecious & 18 & $45.0 \pm 6.9$ & absent & $3.8 \pm 0.2$ & Interlocking & convex & None & & None \\
\hline F. virens Aiton & monoecious & 23 & $9.5 \pm 1.1$ & absent & $2.8 \pm 0.2$ & Interlocking & Convex & $\begin{array}{l}\text { Platyscapa cf } \\
\text { coronata (Grandi) } \\
\text { (105) }\end{array}$ & Yes & None \\
\hline $\begin{array}{l}\text { F. watkinsiana F.M. } \\
\text { Baileys }\end{array}$ & monoecious & 10 & $32.5 \pm 2.2$ & absent & $3.3 \pm 0.2$ & Linear & Convex & $\begin{array}{l}\text { Pleistodontes } \\
\text { imperialis Saunders }^{N} \\
\text { (43) }\end{array}$ & Yes & None \\
\hline
\end{tabular}

$$
\text { (43) }
$$


Overall, pollinating wasps were present in seven fig species, including the three we found to potentially be in the process of naturalizing. Although we found wide variation of germination rates, seeds from these seven species all germinated (Table $\mathbf{1}$ and Supplementary Table 2), whereas the other 16 species without wasps did not develop viable seeds.

The fig wasp Pleistodontes imperialis Saunders (Figure 1) was present in three fig species: Ficus rubiginosa Desf. ex Vent. (the normal host for P. imperialis), F. watkinsiana F.M. Bailey, and F. rubra Vahl (Figure 2A). The first two fig species are sympatric in eastern Australia and are sister in subsection Platypodeae of section Malvanthera. The last fig species is from islands in the western Indian Ocean and is in subsection Platyphyllae of section Galoglychia. We genetically corroborated the identities of Pleistodontes in each host and also of both individuals of F. rubiginosa (GenBank numbers in Supplementary Table 1). Other pollinating wasps in this study associated only with their normal hosts.

The PCA of the morphometric data (Figure $\mathbf{2 B}$ and Supplementary Table 3) reveals that the first 4 of 6 principal component axes account for $97 \%$ of cumulative variation (eigenvalues) among the fig species. In the first PC axis (PC1), the correlation between variation and the original variables (eigenvectors) ranges from 0.264 to 0.512 , with the highest input from the presence of lateral bracts. The greatest eigenvector in PC2 (0.560) is related to syconium diameter. For PC3, the highest eigenvector (0.699) corresponds with the inner ostiolar bracts.

A single canonical axis explains $100 \%$ of the variation in the CDA (Figure 2C), with largest eigenvector (0.983) attributed to the inner ostiolar bracts. The Kolmogorov-Smirnov test shows the morphometric data are not normally distributed $(p<0.01)$, thus we transformed our raw data into $z$-scores for nonparametric analysis. A multivariate logistic regression reflects the $\mathrm{CDA}$ in that the only variable that significantly distinguishes figs based on the presence of $P$. imperialis is the orientation of the inner ostiolar bracts (likelihood ratio $=10.69, p=0.004$ ). We further confirm this assessment with Kruskal-Wallis results $\left(\chi^{2}=11.88, \mathrm{df}=1, p<0.001\right)$ and a post hoc Dunn's multiple comparison test $(z=3.45$, adjusted $p<0.001)$.

\section{DISCUSSION}

We found previously undocumented pollinator interactions between the wasp Pleistodontes imperialis and two fig species, Ficus watkinsiana and F. rubra, despite mechanisms that usually reinforce host-specificity (e.g., Souto-Vilarós et al., 2018). Among figs containing $P$. imperialis, the presence of both mature male and female wasps in the syconia indicates that the wasp can complete its life cycle in different hosts, and the germinated seeds confirm that the wasp is successfully pollinating ovules, thereby completing the fig's life cycle (Figure 1).

Two of the germination rates were notably low (Supplementary Table 2). First, the rate for Ficus macrophylla Desf. ex Pers. was merely $2.9 \%$, even though it may be naturalizing and we found its obligatory pollinator, Pleistodontes froggatti Mayr, emerging from syconia. We detected two genotypes of $P$. froggatti present on Kauai, so perhaps one can successfully reproduce but not pollinate (GenBank numbers in Supplementary Table 1). Further investigation is necessary to learn if Kauai has a less successful genotype of $P$. froggatti. Second, the germination rate for one $F$. rubiginosa tree was $70.2 \%$ but the other was $4.6 \%$. We found two morphs of this species growing in the Lihue-Koloa Forest Reserve (Supplementary Figure 4). While genetics provided support that they are the same species, perhaps one is an unusual variety, and more research may show that it is less suitable to its obligatory pollinator, P. imperialis. Moreover, our germination protocols were standardized so they were not optimized per species, but regardless, all fig species containing pollinator wasps germinated, including those with new pollinator interactions.

The host breadth expansion of P. imperialis from F. rubiginosa to its sister $F$. watkinsiana, sympatric in their native range, appears to involve the absence on Kauai of Pleistodontes nigriventris (Girault), the normal pollinator of $F$. watkinsiana (Lopez-Vaamonde et al., 2002). Haine et al. (2006) conducted a broad-scale mitochondrial analysis across the native range of P. imperialis and detected no evidence of it shifting to other fig species nor of other wasps shifting to F. rubiginosa. Some mechanism is therefore limiting $P$. imperialis in its native range but is absent on Kauai, and the only difference is the occurrence of $P$. nigriventris, implying some form of antagonistic interaction (i.e., competition) between them in their native range. Although some researchers suggest fig wasps may not be limited by direct competition for fig ovules (Hawkins and Compton, 1992; Zhang et al., 2004), perhaps P. nigriventris is better adapted to $F$. watkinsiana and can ostensibly exclude $P$. imperialis in the native range. The realized niche of $P$. imperialis could thus be restricted to F. rubiginosa in Australia, whereas the absence of $P$. nigriventris reveals its fundamental niche to include F. watkinsiana.

However, we also discovered $P$. imperialis successfully using another host that is both distantly related and not overlapping in range with its normal host: F. rubra (Galoglychia: Platyphyllae; Figure 2A). Two other fig species did not contain P. imperialis despite being related to those that did: (i) F. macrophylla in section Malvanthera that instead contained its normal pollinator, and (ii) F. saussureana De Candolle in section Galoglychia that lacked its normal pollinator (Table 1). These absences suggest that neither phylogenetic relationship nor alleviated competition can fully explain which Ficus hosts $P$. imperialis can use on Kauai. Our results instead strongly support our hypothesis that convergent evolution is a driving factor, particularly regarding the arrangement of the inner ostiolar bracts that are tightly correlated with the presence of $P$. imperialis (Figure 2C). Our findings concur with work by Jousselin et al. (2003), who also found homoplasy of the ostioles across fig sections; now our analysis further implicates this trait as strongly influencing in the ability of $P$. imperialis to utilize new hosts.

This opens the investigation to other causes of the reduced specificity of $P$. imperialis, and by contrast the apparent maintained specificity of the other four pollinating wasps in this study (Table 1 and Supplementary Material). We examined six morphological traits, but others may exist that further distinguish 


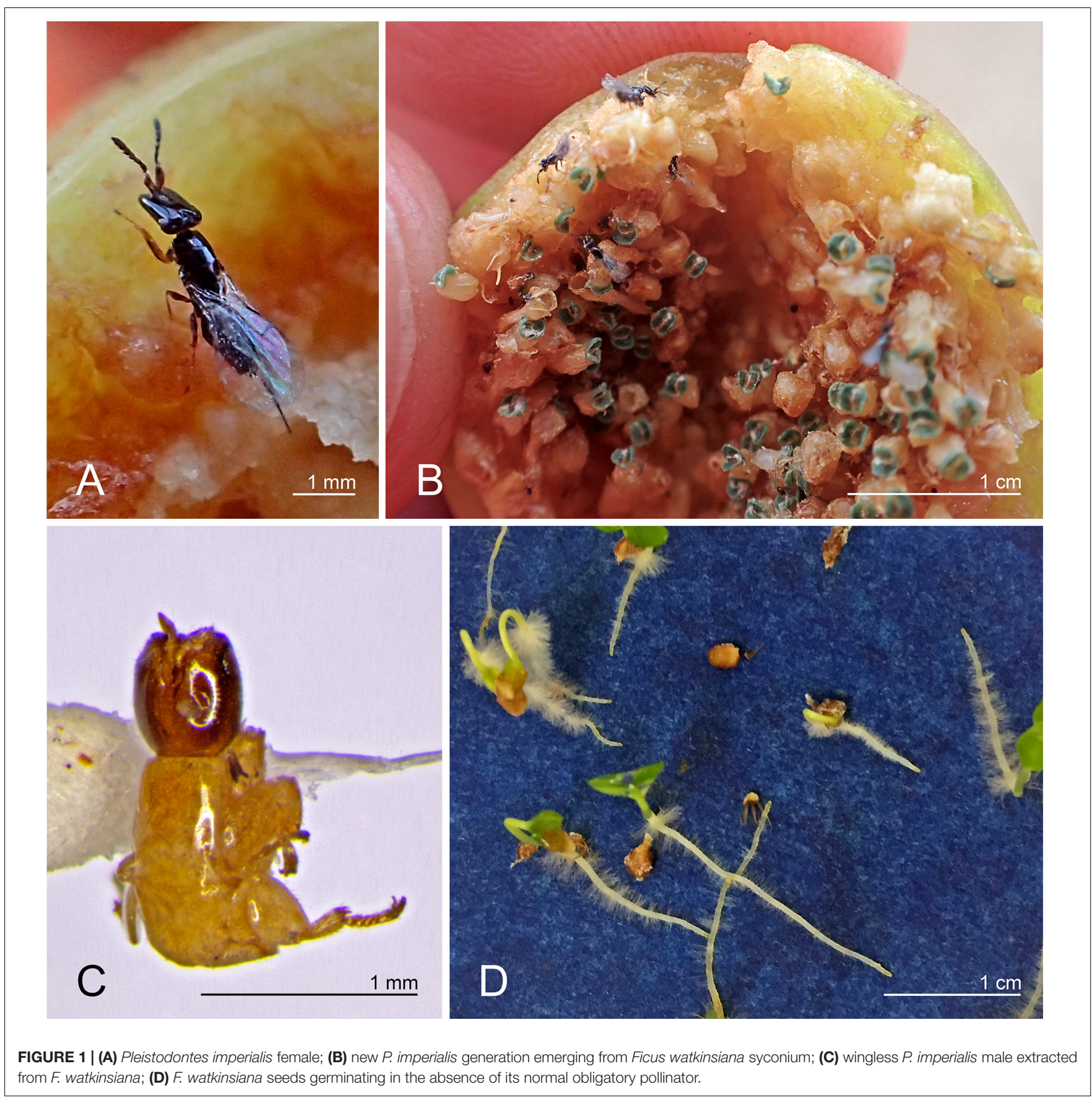

figs that share a pollinator, for instance synchronized phenology between pollinators and syconia development. Although we found wasp-bearing syconia on our pollinator-sharing species at numerous times during our collection period (Supplementary Material), additional work is needed to explore this possibility. Another trait that is almost undoubtedly involved in forming new pollinator interactions is scent. Because figs use volatile compounds to attract specific pollinators (Grison-Pigé et al., 2002; Proffit et al., 2009; Hossaert-McKey et al., 2010; Souza et al., 2015), any new pollinator would very likely need to be attracted to the same cues. Similarity of volatile compounds alongside that of the ostiole could drive pollinator sharing, such as Cornille et al. (2012) detected between sympatric sister fig species in South Africa.

On the North Island of New Zealand, non-native figs include F. rubiginosa and F. obliqua G.Forst. (Gardner and Early, 1996), both of which are in subsection Platypodeae and have overlapping native ranges in Australia (Dixon, 2003; Rønsted et al., 2008), although only the former is naturalized due to the introduction of P. imperialis. Gardner and Early (1996) noted P. imperialis in many syconia of $F$. obliqua, yet despite the absence of the normal pollinator for F. obliqua in New Zealand, P. imperialis 


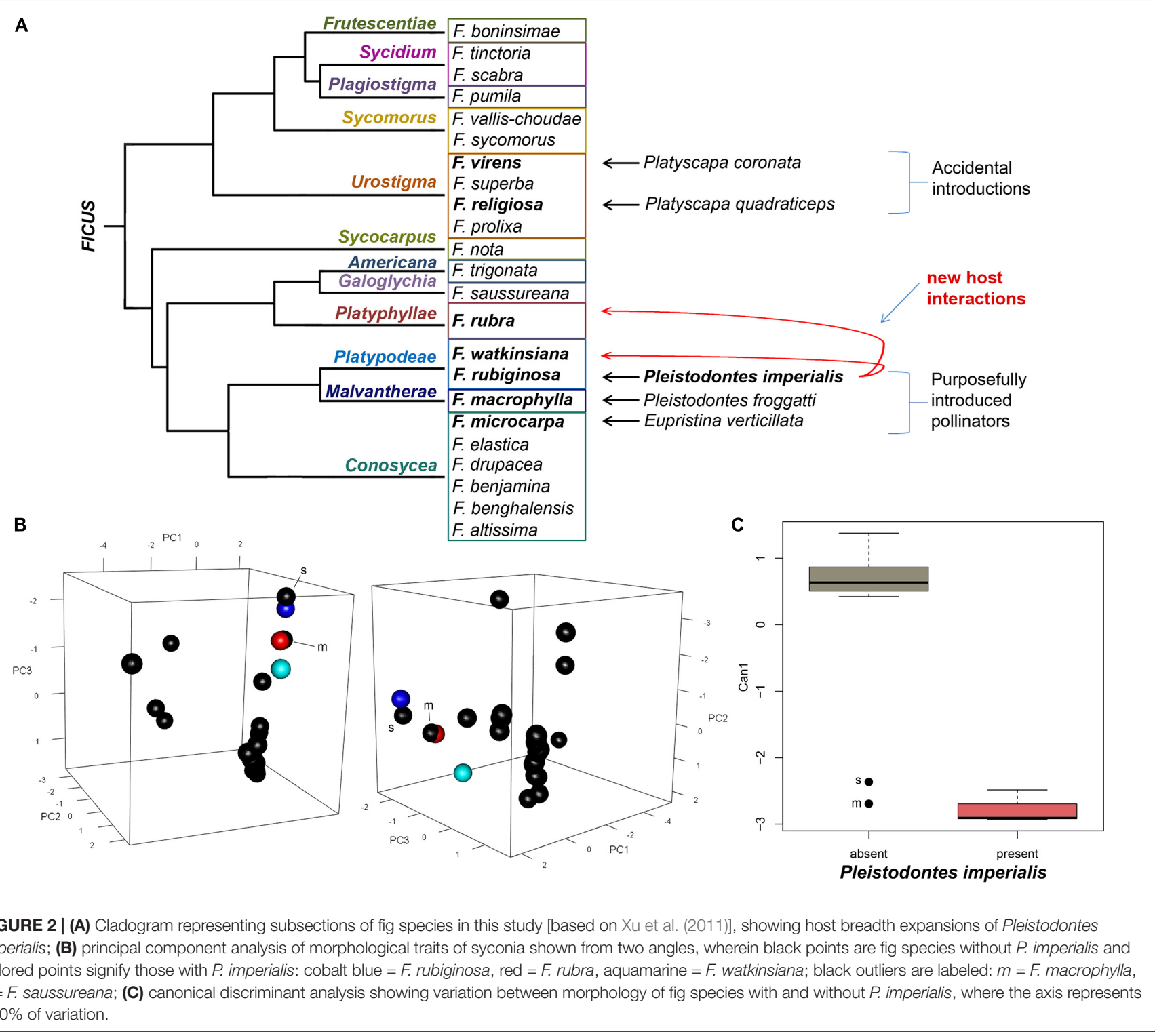

was unable to pollinate the ovules, no seed development took place, and the authors remarked that females were "stuck in the ostiole." In this situation, F. obliqua probably produces similar volatile compounds to $F$. rubiginosa that are necessary to attract $P$. imperialis, but a divergent internal ostiole morphology rather than competition seems to be preventing $P$. imperialis from using $F$. obliqua as a host. This obstacle is alleviated in F. watkinsiana because its ostiolar morphology is homologous with that of $F$. rubiginosa, in which case competition may be a more important factor in limiting pollinators in the native range. This concept is congruent with work by Rønsted et al. (2008), which describes both $F$. rubiginosa and F. watkinsiana as having triradiate ostioles, whereas $F$. obliqua (in a sister series) has a bilabiate ostiole.

For the expansion of $P$. imperialis's host breadth to include F. rubra, convergent evolution of the inner ostiole morphology, and most likely also the volatile compounds required to attract the wasp (Grison-Pigé et al., 2002; Proffit et al., 2009; Cornille et al., 2012), appears to be necessary. Whether P. imperialis benefits from the absence of $F$. rubra's normal pollinator is unclear. The absence of this wasp in $F$. saussureana, in spite of clustering with its other new hosts in the PCA (Figure 2B) and no normal pollinator, implies that a trait not measured in this study was preventing its use of $F$. saussureana. Because we found no indication that $P$. imperialis was attempting to enter the syconia of $F$. saussureana, as it did with F. obliqua in New Zealand (Gardner and Early, 1996), the limiting factor in this case could be volatile compounds (Proffit et al., 2009). We also did not detect $P$. imperialis attempting to enter the syconia of F. macrophylla, whose morphology also clusters with the pollinator-sharing figs. Whether this stems from competition with the present normal pollinator or from dissimilar volatile compounds is not clear.

Here we elaborate on Thompson's (2005) geographic mosaic theory of context-dependent coevolution by showing that an 
established obligatory mutualism subjected to a new species assemblage is unstable as a result of unprecedented species interactions. Pleistodontes imperialis can form new relationships on Kauai because its interaction with the normal pollinator for F. watkinsiana is missing, which may disincentivize niche partitioning, and because it can now interact with F. rubra, which has an analogous ostiole shape to that of its normal host. Our findings therefore also show the relevance of the rest of the species interactions in the native community, rather than only the two in the partnership, in forming the mechanisms that maintain a relationship. A deeper exploration of new species interactions among coexisting non-native figs will likely uncover other novel instances of pollinator sharing or co-pollination. Such occurrences stipulate long-held views on coevolution by emphasizing the importance of native species assemblages in forming mutualisms, and that they can be disrupted in the new communities of the Anthropocene.

\section{DATA AVAILABILITY STATEMENT}

The original contributions presented in the study are included in the article/Supplementary Material, further inquiries can be directed to the corresponding author.

\section{AUTHOR CONTRIBUTIONS}

KB conceptualized the project, surveyed Kauai for potentially naturalizing fig species, and identified fig species taxonomically. $\mathrm{KB}, \mathrm{JB}, \mathrm{SW}$, and DW collected samples in the field. JW and GW identified Ficus rubiginosa with genetics. SW and DW conducted

\section{REFERENCES}

Adler, D., Murdoch, D., Nenadic, O., Urbanek, S., Chen, M., Gebhardt, A., et al. (2018). rgl: 3D Visualization using OpenGL. R Package Version 0.99.16. Available online at: https://CRAN.R-project.org/package=rgl (accessed April 26, 2018).

Anstett, M. C., Hossaert-McKey, M., and Kjellberg, F. (1997). Figs and fig pollinators: evolutionary conflicts in a coevolved mutualism. Trends Ecol. Evol. 12, 94-99. doi: 10.1016/S0169-5347(96)1 0064-1

Bain, A., Tzeng, H.-Y., Wu, W.-J., and Chou, L.-S. (2015). Ficus (Moraceae) and fig wasps (Hymenoptera: Chalcidoidea) in Taiwan. Bot. Stud. 56:11. doi: 10.1186/ s40529-015-0090-x

Beardsley, J. W. (1998). Chalcid wasps (Hymenoptera: Chalcidoidea) associated with fruit of Ficus microcarpa in Hawaii. P. Hawaii. Entomol. Soc. 33, 19-34.

Beardsley, J. W. (1999). Hymenoptera from midway atoll. Bishop Mus. Occas. Pap. $58,37-50$.

Beardsley, J. W., and Rasplus, J.-Y. (2001). A new species of Josephiella (Hymenoptera: Agaonidae) forming leaf galls on Ficus microcarpa L. (Moraceae). J. Nat. Hist. 35, 33-40. doi: 10.1080/002229301447871

Berg, C. C. (1989). Classification and distribution of Ficus. Experientia 45, 605-611. doi: 10.1007/BF01975677

Berg, C. C., and Wiebes, J. T. (1992). African Fig Trees and Fig Wasps. Verhandelingen Afdeling Natuurkunde, Vol. 89. Amsterdam: Koninkliijke Nederlandse Akademie van Wetenschappen.

Compton, S. G., Grehan, K., and van Noort, S. (2009). A fig crop pollinated by three or more species of agaonid fig wasps. Afr. Entomol. 17, 215-222. doi: 10.4001/003.017.0212 seed germination assays. JB identified wasp species taxonomically and collected, analyzed, and interpreted morphometric data, and wrote the manuscript. VT and GW verified Pleistodontes wasp identifications with genetics. All authors reviewed and edited the manuscript.

\section{FUNDING}

Contributions from KB were supported in part by funds acquired by the Kauai Invasive Species Committee.

\section{ACKNOWLEDGMENTS}

We are grateful to Timothy Flynn from the National Tropical Botanical Garden for guiding us into the Lihue-Koloa Forest Reserve. For their assistance with germination assays, we thank Margaret Clark, Shyla Kaninauali'i Villanueva, Jeffrey Frelinger, Leilani Naki, Sherry Hines, and Phyllis Albert. We furthermore appreciate Alex Lau with SWCA ${ }^{\circledR}$ Environmental Consultants for knowledge about the first viable seeds of F. religiosa $\mathrm{L}$. recorded on Oahu Island. For informing KB about a volunteer F. religiosa specimen in Lihue, Kauai, we also thank Adam Williams with the Hawaii Department of Land and Natural Resources.

\section{SUPPLEMENTARY MATERIAL}

The Supplementary Material for this article can be found online at: https://www.frontiersin.org/articles/10.3389/fevo.2020. 564653/full\#supplementary-material

Cook, J. M., and Rasplus, J.-Y. (2003). Mutualists with attitude: coevolving fig wasps and figs. Trends Ecol. Evol. 18, 241-248. doi: 10.1016/S0169-5347(03) 00062-4

Corner, E. J. H. (1962). Taxonomic notes on Ficus L., Asia and Australasia: addendum II. Gard. Bull. 19, 385-401.

Corner, E. J. H. (1965). Check-list of Ficus in Asia and Australasia with keys to identification. Gard. Bull. Singapore 21, 1-186.

Cornille, A., Underhill, J. G., Cruaud, A., Hossaert-McKey, M., Johnson, S. D., Tolley, K. A., et al. (2012). Floral volatiles, pollinator sharing and diversification in the fig-wasp mutualism: insights from Ficus natalensis, and its two wasp pollinators (South Africa). Proc. R. Soc. B 279, 1731-1739. doi: 10.1098/rspb. 2011.1972

Coyne, J. A., and Orr, H. A. (2004). Speciation. Sunderland, MA: Sinauer Associates Inc.

Cruaud, A., Cook, J. M., Yang, D.-R., Genson, G., Jabbour-Zahab, R., Kjellberg, F., et al. (2012a). "Fig-fig wasp mutualism: the fall of the strict cospeciation paradigm?" in Evolution of Plant-Pollinator Relationships, ed. S. Patiny (Cambridge, MA: Cambridge University Press), 68-102. doi: 10.1017/ CBO9781139014113

Cruaud, A., Rønsted, N., Chantarasuwan, B., Chou, L.-S., Clement, W. L., Couloux, A., et al. (2012b). An extreme case of plant-insect codiversification: figs and fig-pollinating wasps. Syst. Biol. 61, 1029-1047. doi: 10.1093/sysbio/sys068

Danforth, B. N., and Ascher, J. (1999). Flowers and insect evolution. Science 283:143a. doi: 10.1126/science.283.5399.143a

Dinno, A. (2017). dunn.test: Dunn's Test of Multiple Comparisons Using Rank Sums. R Package Version 1.3.5. Available online at: https:/CRAN.R-project.org/ package=dunn.test (accessed April 26, 2018). 
Dixon, D. J. (2003). A taxonomic revision of the Australian Ficus species in the section Malvanthera (Ficus subg. Urostigma: Moraceae). Telopea 10, 125-153. doi: $10.7751 /$ telopea20035611

Ehrlich, P. R., and Raven, P. H. (1964). Butterflies and plants: a study in coevolution. Evolution 18, 586-608. doi: 10.1111/j.1558-5646.1964.tb01674.x

Friendly, M., and Fox, J. (2017). candisc: Visualizing Generalized Canonical Discriminant and Canonical Correlation Analysis. R Package Version 0.8 0 . Available online at: https://CRAN.R-project.org/package $=$ candisc (accessed April 26, 2018).

Gardner, R. O., and Early, J. W. (1996). The naturalisation of banyan figs (Ficus spp., Moraceae) and their pollinating wasps (Hymenoptera: Agaonidae) in New Zealand. New Zeal. J. Bot. 34, 103-110. doi: 10.1080/0028825X.1996. 10412697

Grison-Pigé, L., Bessière, J.-M., and Hossaert-McKey, M. (2002). Specific attraction of fig-pollinating wasps: role of volatile compounds released by tropical figs. J. Chem. Ecol. 28, 283-295. doi: 10.1023/A:1017930023741

Hafner, M. S., and Page, R. D. M. (1995). Molecular phylogenies and host-parasite cospeciation: gophers and lice as a model system. Proc. R. Soc. B 349, 77-83. doi: $10.1098 /$ rstb.1995.0093

Haine, E. R., Martin, J., and Cook, J. M. (2006). Deep mtDNA divergences indicate cryptic species in a fig-pollinating wasp. BMC Evol. Biol. 6:83. doi: 10.1186/ 1471-2148-6-83

Hawkins, B. A., and Compton, S. G. (1992). African fig wasp communities: undersaturation and latitudinal gradients in species richness. J. Anim. Ecol. 61, 361-372. doi: 10.2307/5328

Herre, E. A., Jander, K. C., and Machado, C. A. (2008). Evolutionary ecology of figs and their associates: recent progress and outstanding puzzles. Annu. Rev. Ecol. Evol. Syst. 39, 439-458. doi: 10.1146/annurev.ecolsys.37.091305.110232

Hossaert-McKey, M., Soler, C., Schatz, B., and Proffit, M. (2010). Floral scents: their roles in nursery pollination mutualisms. Chemoecology 20, 75-88. doi: 10.1007/s00049-010-0043-5

Ishii, T. (1934). Fig chalcidoids of Japan. Kontyû 8, 84-100.

Janz, N., Nylin, S., and Wahlberg, N. (2006). Diversity begets diversity: host expansions and the diversification of plant-feeding insects. BMC Evol. Biol. 6:4. doi: 10.1186/1471-2148-6-4

Jousselin, E., Desdevises, Y., and Coeur d'Acier, A. (2009). Fine-scale cospeciation between Brachycaudus and Buchnera aphidicola: bacterial genome helps define species and evolutionary relationships in aphids. Proc. R. Soc. B 276, 187-196. doi: $10.1098 / \mathrm{rspb} .2008 .0679$

Jousselin, E., Rasplus, J.-Y., and Kjellberg, F. (2003). Convergence and coevolution in a mutualism: evidence from a molecular phylogeny of Ficus. Evolution 57, 1255-1269. doi: 10.1554/02-445

Kawakita, A., and Kato, M. (2009). Repeated independent evolution of obligate pollination mutualism in the Phyllantheae-Epicephala association. Proc. R. Soc. B 276, 417-426. doi: 10.1098/rspb.2008.1226

Liu, C., Yang, D.-R., Compton, S. G., and Peng, Y.-Q. (2013). Larger fig wasps are more careful about which figs to enter - with good reason. PLoS One 8:e74117. doi: 10.1371/journal.pone.0074117

Lopez-Vaamonde, C., Dixon, D. J., Cook, J. M., and Rasplus, J.-Y. (2002). Revision of the Australian species of Pleistodontes (Hymenoptera: Agaonidae) figpollinating wasps and their host-plant associations. Zool. J. Linn. Soc. Lond. 136, 637-683. doi: 10.1046/j.1096-3642.2002.00040.x

Lopez-Vaamonde, C., Rasplus, J.-Y., Weiblen, G., and Cook, J. M. (2001). Molecular phylogenies of fig wasps: partial cocladogenesis between pollinators and parasites. Mol. Phylogenet. Evol. 21, 55-71. doi: 10.1006/mpev.2001.0993

Lunau, K. (2004). Adaptive radiation and coevolution-pollination biology case studies. Organ. Divers. Evol. 4, 207-224. doi: 10.1016/j.ode.2004.02.002

Machado, C. A., Robbins, N., Gilbert, M. T. P., and Herre, E. A. (2005). Critical review of host specificity and its coevolutionary implications in the fig/fig-wasp mutualism. Proc. Natl. Acad. Sci. U.S.A. 102, 6558-6565. doi: 10.1073/pnas. 0501840102

McKenna, D. D., Shin, S., Ahrens, D., Balke, M., Beza-Beza, C., Clarke, D. J., et al. (2019). The evolution and genomic basis of beetle diversity. Proc. Natl. Acad. Sci. U.S.A. 116, 24729-24737. doi: 10.1073/pnas.1909655116

Moe, A. M., and Weiblen, G. D. (2010). Molecular divergence in allopatric Ceratosolen (Agaonidae) pollinators of geographically widespread Ficus (Moraceae) species. Ann. Entomol. Soc. Am. 103, 1025-1037. doi: 10.1603/ AN10083
Moe, A. M., and Weiblen, G. D. (2012). Pollinator-mediated reproductive isolation among dioecious fig species (Ficus, Moraceae). Evolution 66, 3710-3721. doi: 10.1111/j.1558-5646.2012.01727.x

Pellmyr, O., and Leebens-Mack, J. (1999). Forty million years of mutualism: evidence for Eocene origin of the yucca-yucca moth association. Proc. Natl. Acad. Sci. U.S.A. 96, 9178-9183. doi: 10.1073/pnas.96.16.9178

Percy, D. M. (2010). "Insect-plant interactions on islands: codiversification of legume-feeding psyllids (Psylloidea) and their Fabaceae hosts," in Terrestrial Arthropods of Macaronesia: Biodiversity, Ecology and Evolution, eds A. R. M. Serrano, P. A. V. Borges, M. Boieiro, and P. Oromí (Lisbon: Fundação para Ciência e a Tecnologia), 285-308.

Proffit, M., Chen, C., Soler, C., Bessière, J.-M., Schatz, B., and Hossaert-McKey, M. (2009). Can chemical signals, responsible for mutualistic partner encounter, promote the specific exploitation of nursery pollination mutualisms? The case of figs and fig wasps. Entomol. Exp. Appl. 131, 46-57. doi: 10.1111/j.1570-7458. 2009.00823.x

R Core Team (2019). R: A Language and Environment for Statistical Computing. Vienna: R Foundation for Statistical Computing.

Ramírez-Benavides, W. (1970). Host specificity of fig wasps (Agaonidae). Evolution 24, 680-691. doi: 10.1111/j.1558-5646.1970.tb01804.x

Rønsted, N., Weiblen, G. D., Cook, J. M., Salamin, N., Machado, C. A., and Savolainen, V. (2005). 60 million years of co-divergence in the fig-wasp symbiosis. Proc. R. Soc. B 272, 2593-2599. doi: 10.1098/rspb.2005.3249

Rønsted, N., Weiblen, G. D., Savolainen, V., and Cook, J. M. (2008). Phylogeny, biogeography, and ecology of Ficus section Malvanthera (Moraceae). Mol. Phylogenet. Evol. 48, 12-22. doi: 10.1016/j.ympev.2008. 04.005

Shimizu, A., Dohzono, I., Nakaji, M., Roff, D. A., Miller, D. G. I. I. I., Osato, S., et al. (2015). Fine-tuned bee-flower coevolutionary state hidden within multiple pollination interactions. Sci. Rep. 4:3988. doi: 10.1038/srep03988

Souto-Vilarós, D., Proffit, M., Buatois, B., Rindos, M., Sisol, M., Kuyaiva, T., et al. (2018). Pollination along an elevational gradient mediated both by floral scent and pollinator compatibility in the fig and fig-wasp mutualism. J. Ecol. 106, 2256-2273. doi: 10.1111/1365-2745.12995

Souza, C. D., Pereira, R. A. S., Marinho, C. R., Kjellberg, F., and Teixeira, S. P. (2015). Diversity of fig glands is associated with nursery mutualism in fig trees. Am. J. Bot. 102, 1-14. doi: 10.3732/ajb.1500279

Suleman, N., Sait, S., and Compton, S. G. (2015). Female figs as traps: their impact on the dynamics of an experimental fig tree-pollinator-parasitoid community. Acta Oecol. 62, 1-9. doi: 10.1016/j.actao.2014.11.001

Thompson, J. N. (2005). The Geographic Mosaic of Coevolution. Chicago: University of Chicago Press.

Timberlake, P. H. (1924). Records of the introduced and immigrant chalcid-flies of the Hawaiian Islands (Hymenoptera). Proc. Hawaii. Entomol. Soc. 5, 418-449.

Tsai, L., Hayakawa, H., Fukuda, T., and Yokoyama, J. (2015). A breakdown of obligate mutualism on a small island: an interspecific hybridization between closely related fig species (Ficus pumila and Ficus thunbergii) in Western Japan. Am. J. Plant Sci. 6, 126-131. doi: 10.4236/ajps.2015.61014

van Kleunen, M., Dawson, W., Essl, F., Pergl, J., Winter, M., Weber, E., et al. (2015). Global exchange and accumulation of non-native plants. Nature 525, 100-103. doi: $10.1038 /$ nature 14910

van Noort, S., and Compton, S. G. (1996). Convergent evolution of agaonine and sycoecine (Agaonidae, Chalcidoidea) head shape in response to the constraints of host fig morphology. J. Biogeogr. 23, 415-424. doi: 10.1111/j.1365-2699.1996. tb00003.x

van Noort, S., and Rasplus, J.-Y. (1997). Revision of the otiteselline fig wasps (Hymenoptera: Chalcidoidea: Agaonidae), l: the Otitesella digitata speciesgroup of the Afrotropical Region, with a key to Afrotropical species of Otitesella Westwood. Afr. Entomol. 5, 125-147.

van Noort, S., and Rasplus, J.-Y. (2010). Order Hymenoptera, Chalcidoidea associated with figs (families Agaonidae and Pteromalidae). Arthropod Fauna UAE 3, 325-355.

van Noort, S., Wang, R., and Compton, S. G. (2013). Fig wasps (Hymenoptera: Chalcidoidea: Agaonidae, Pteromalidae) associated with Asian fig trees (Ficus, Moraceae) in southern Africa: Asian followers and African colonists. Afr. Invertebr. 54, 381-400. doi: 10.5733/afin.054. 0208

Verkerke, W. (1989). Structure and function of the fig. Experientia 45, 612-622. 
Wachi, N., Kusumi, J., Tzeng, H.-Y., and Su, Z.-H. (2016). Genome-wide sequence data suggest the possibility of pollinator sharing by host shift in dioecious figs (Moraceae, Ficus). Mol. Ecol. 25, 5732-5746. doi: 10.1111/mec.13876

Wang, G., Cannon, C. H., and Chen, J. (2016). Pollinator sharing and gene flow among closely related sympatric dioecious fig taxa. Proc. R. Soc. B 283:20152963. doi: 10.1098/rspb.2015.2963

Wang, G., Compton, S. G., and Chen, J. (2013). The mechanism of pollinator specificity between two sympatric fig varieties: a combination of olfactory signals and contact cues. Ann. Bot. 111, 173-181. doi: 10.1093/aob/mcs250

Wang, R., Aylwin, R., Barwell, L., Chen, X.-Y., Chen, Y., Chou, L.-S., et al. (2015). The fig wasp followers and colonists of a widely introduced fig tree, Ficus microcarpa. Insect Conserv. Diver. 8, 322-336. doi: 10.1111/icad.12111

Wang, Y., Naumann, U., Eddelbuettel, D., Wilshire, J., and Warton, D. (2019). mvabund: Statistical Methods for Analysing Multivariate Abundance Data. $R$ Package Version 4.0.1. Available online at: https://CRAN.R-project.org/ package=mvabund (accessed June 8, 2019).

Wang, Y., Naumann, U., Wright, S. T., and Warton, D. I. (2012). mvabund: an $\mathrm{R}$ package for model-based analysis of multivariate abundance data. Methods Ecol. Evol. 3, 471-474. doi: 10.1111/j.2041-210X.2012.00 190.x

Wei, Z.-D., Kobmoo, N., Cruaud, A., and Kjellberg, F. (2014). Genetic structure and hybridization in the species group of Ficus auriculata: can closely related sympatric Ficus species retain their genetic identity while sharing pollinators? Mol. Ecol. 23, 3538-3550. doi: 10.1111/mec. 12825

Weiblen, G. D. (2000). Phylogenetic relationships of functionally dioecious Ficus (Moraceae) based on ribosomal DNA sequences and morphology. Am. J. Bot. 87, 1342-1357.

Weiblen, G. D. (2002). How to be a fig wasp. Annu. Rev. Entomol. 47, 299-330. doi: 10.1146/annurev.ento.47.091201.145213

Wiebes, J. T. (1964). Indo-Malayan and Papuan fig wasps (Hymenoptera, Chalcidoidea); 3. Insects from Ficus conocephalifolia, with a note on the Sycophaginae, Nova Guinea. Zoology 27, 75-86.

Wiebes, J. T. (1994). The Indo-Australian Agaoninae (Pollinators of Figs). Amsterdam: Koninklijke Nederlandse Akademie van Wetenschappen.
Wiens, J. J., Lapoint, R. T., and Whiteman, N. K. (2015). Herbivory increases diversification across insect clades. Nat. Commun. 6:8370. doi: 10.1038/ ncomms 9370

Winter, S., Friedman, A. L. L., Astrin, J. J., Gottsberger, B., and Letsch, H. (2017). Timing and host plant associations in the evolution of the weevil tribe Apionini (Apioninae, Brentidae, Curculionoidea, Coleoptera) indicate an ancient co-diversification pattern of beetles and flowering plants. Mol. Phylogenet. Evol. 107, 179-190. doi: 10.1016/j.ympev.2016.10. 015

Xu, L., Harrison, R. D., Yang, P., and Yang, D.-R. (2011). New insight into the phylogenetic and biogeographic history of genus Ficus: vicariance played a relatively minor role compared with ecological opportunity and dispersal. J. Syst. Evol. 49, 546-557. doi: 10.1111/j.1759-6831.2011.00 155.X

Yang, L.-Y., Machado, C. A., Dang, X.-D., Peng, Y.-Q., Yang, D.-R., Zhang, D.Y., et al. (2015). The incidence and pattern of co-pollinator diversification in dioecious and monoecious figs. Evolution 69, 294-304. doi: 10.1111/evo. 1258

Yang, P., Li, Z., Peng, Y., and Yang, D. (2012). Exchange of hosts: can agaonid fig wasps reproduce successfully in the figs of non-host Ficus? Naturwissenschaften 99, 199-205. doi: 10.1007/s00114-012-0885-5

Zhang, D.-Y., Lin, K., and Hanski, I. (2004). Coexistence of cryptic species. Ecol. Lett. 7, 165-169. doi: 10.1111/j.1461-0248.2004.00569.x

Conflict of Interest: The authors declare that the research was conducted in the absence of any commercial or financial relationships that could be construed as a potential conflict of interest.

Copyright (c) 2020 Bernard, Brock, Tonnell, Walsh, Wenger, Wolkis and Weiblen. This is an open-access article distributed under the terms of the Creative Commons Attribution License (CC BY). The use, distribution or reproduction in other forums is permitted, provided the original author(s) and the copyright owner(s) are credited and that the original publication in this journal is cited, in accordance with accepted academic practice. No use, distribution or reproduction is permitted which does not comply with these terms. 